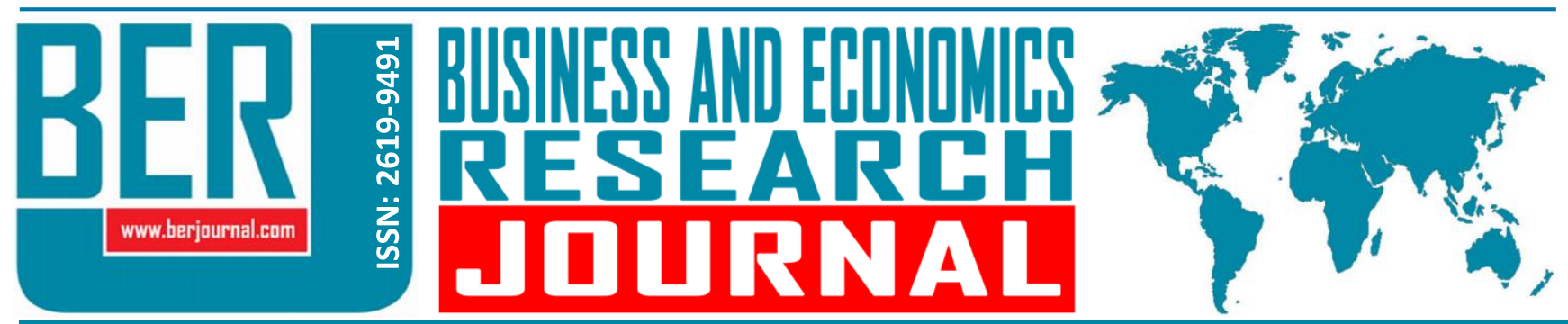

Business and Economics Research Journal Vol. 11, No. 4, 2020, pp. 1069-1081 doi: 10.20409/berj.2020.299

\section{Kompulsif Satın Alma Eğiliminde Materyalizm ve Hedonik Tüketimin Rolü: Aktüel Ürünler Satın Alan Kadın Tüketiciler Üzerinde Bir Araştırma}

\section{Emine Senbabaoglu Danaci ${ }^{\mathrm{a}}$}

Öz: Günümüz tüketicileri, farklı amaçlar dolayısıyla farklı motivasyonlar aracılığıyla tüketime yönelmektedir. Duyguları doğrultusunda hareket eden tüketicilerin gün geçtikçe arttığının gözlemlenmesi ise çalışma kapsamında incelenen faktörlerin önemini artırmaktadır. Bu çalışmayla aktüel ürünler satın alan kadın tüketiciler üzerinde araştırma yapılmıştır. "Aktüel ürünler" haftada belirlenen bir ya da iki gün olmaküzere periyodik olarak, sınırlı sayıda satışa sunulan, farklı kategori ve markalardaki ürün gruplarıdır. Söz konusu ürün grubuna ilişkin pazarlama perspektifi açısından sınırlı sayıda çalışma yapılmıştır. Oysa oldukça yüksek talep edeni bulunan ve pazar payının oldukça yüksek olduğu bilinen bir alandır. Çalışmanın amacı, aktüel ürün satın alan kadın tüketicilerin materyalizm ve hedonik tüketim eğilimlerinin kompulsif satın alma eğilimi üzerindeki etkisini incelemektir. Araştırma kapsamında, kolayda örnekleme yöntemiyle ulaşılan 395 kadın tüketiciden anket tekniği kullanılarak veri toplanmıştır. Verilerin analizinde SPSS ve SmartPLS paket programlarının kullanıldığı çalışmanın sonucunda, aktüel ürün satın alan kadın tüketicilerin materyalizm ve hedonik tüketim eğiliminin kompulsif satın alma eğilimi üzerinde olumlu etkisinin olduğu bulgusuna ulaşılmıştır.

\section{The Role of Materialism and Hedonic Consumption on Compulsive Buying Tendency: A Study on Female Consumers Buying Actual Products}

\begin{abstract}
Today's consumers tend towards consumption through different motivations for different purposes. Observing that the consumers acting in line with their emotions are increasing day by day, increases the importance of the factors examined within the scope of the study. With this study, research was conducted on female consumers who purchase actual products. "Actual products" are product groups in different categories and brands that are periodically offered for sale in a limited number of days, determined for one or two days a week. Researches were done from a very limited number of marketing perspectives regarding the product group in question. However, it is an area with a very high demand and known to have a high market share. The aim of this study is to examine the effect of materialism and hedonic consumption tendency of female consumers buying actual products on compulsive buying tendency. Within the scope of the research, data were collected from 395 female consumers who were reached by convenience sampling method, using the survey technique. As a result of the study in which SPSS and SmartPLS package programs were used in the analysis of the data, it was found that the materialism and hedonic consumption tendency of female consumers who purchased actual products had a positive effect on the compulsive buying tendency.
\end{abstract}

Anahtar Sözcükler: Kompulsif Satın Alma Eğilimi, Materyalizm, Hedonik Tüketim Eğilimi, Aktüel Ürün

JEL: M10, M31, C12

$\begin{array}{ll}\text { Geliş } & : 20 \text { Mayıs } 2020 \\ \text { Düzeltme } & : 17 \text { Temmuz } 2020 \\ \text { Kabul } & : 21 \text { Ağustos } 2020 \\ \text { Tür } & : \text { Araştırma }\end{array}$

Keywords: Compulsive Buying Tendency, Materialism, Hedonic Consumption Tendency, Actual Product

JEL: M10, M31, C12

$\begin{array}{ll}\text { Received } & : 20 \text { May } 2020 \\ \text { Revised } & : 17 \text { July } 2020 \\ \text { Accepted } & : 21 \text { August } 2020\end{array}$

Type : Research 


\section{Giriş}

"Aktüel ürünler" haftada belirlenen bir ya da iki gün için periyodik olarak sınırlı sayıda farklı kategori ve markalarda mağazada satışa sunulan ürün gruplarıdır. Söz konusu ürün grubuna ilişkin pazarlama perspektifinden oldukça sınırlı sayıda araştırma yapılmıştır (Akçi ve Kılınç, 2016; Başfırıncı, Ük ve Gültekin, 2019). Halbuki pazara göre daha uygun fiyatlandırılabilen bu ürünlere olan talebin düzeyi yüksek, dolayısıyla pazar payı da geniştir. İşletmelerin tutundurma stratejisi olarak kullandıkları bu uygulama, Bim, Migros, A101, Carrefoursa, Şok, Tedi, Metro gibi çok sayıda markette uygulanmaktadır.

"Tüketim toplumu" olarak nitelenen günümüz tüketicileri yalnızca temel ihtiyaçların karşılanması amacıyla tüketime yönelmemektedir. Aynı zamanda keyif, eğlence, heyecan, haz ve mutluluk amacıyla da alışveriş gerçekleştirmektedir. Özellikle psikoloji alanındaki çeşitli çalışmalarda sıklıkla incelenen kompulsif satın alma eğilimine, bağımlıık, depresyon, özgüven eksikliği, kaygı bozukluğu, materyalizm, hazcı duygular ve mükemmeliyetçilik gibi faktörlerin sebep olduğu tespit edilmiştir (DeSarbo, 1996: 232). Tüketicilerin satın alma karar sürecinde, rasyonelite etkisinin azalmasıyla birlikte hem uygulamada hem de teoride çalışma alanı bulan kompulsif satın alma eğilimi, hedonik tüketim ve materyalizm bu çalışmada bir arada incelenmiştir. Araştırmanın temel sorusu, aktüel ürün satın alan kadın tüketicilerin, materyalizm ve hedonik tüketim eğilimlerinin, kompulsif satın alma eğilimlerini ne düzeyde etkilediğini açıklamaya ilişkindir. Söz konusu olgular, toplumu etkileyen oldukça önemli ekonomik ve sosyal sonuçlar doğuran faktörlerdir. İçinde bulunduğumuz toplum, materyalist değerleri ön planda tutarak kompulsif satın almaya ve hedonik tüketime yönlendirebilmektedir. Özellikle dönemsel ihtiyaçlara hitap eden aktüel ürün satışının, kompulsif satın almaya ve hedonik tüketime neden olduğu düşünülmektedir. Literatürde kompulsif satın almanın, materyalizm ve hedonik tüketim eğilimi ile birlikte ele alındığı araştırmaya rastlanmamıştır.

Çalışmaya öncelikle kompulsif satın alma eğilimine ilişkin teorik çerçeve oluşturularak başlanmaktadır. Ardından kompulsif satın almaya etki ettiği düşünülen faktörlerden olan materyalizm ve hedonik tüketim eğilimi açıklanmaktadır. Kompulsif satın almanın belirleyicileri üzerinde durulduktan sonra, değişkenler arasındaki ilişkiler incelenerek kurgulanan hipotezler ve neticesinde oluşturulan araştırma modeli ortaya koyulmaktadır. Gerçekleştirilen analiz sonrasında ise elde edilen bulgulara ve yorumlamalara yer verilmektedir. Takiben, araştırmanın kısıtları ve ileride yapılacak olan araştırmalar için öneriler ise sonuç bölümünde açıklanmaktadır.

\section{Literatür Analizi}

\subsection{Kompulsif Satın Alma Eğilimi}

Kompulsif satın alma, olumsuz olay ve duygular karşısında gelişen kronik ve tekrarlayan satın alma davranışı olarak tanımlanmaktadır (O'Guinn ve Faber, 1989: 149). Dittmar'a (2005: 467) göre kompulsif satın alma, olumsuz psikolojik ve finansal sonuçları olan işlevsel olmayan bir tüketici davranışıdır. Bir diğer tanımlamada Bhatia (2019) kompulsif satın almayı, rasyonel olmayan bir şekilde kontrol edilemeyen aşırı düzeyde bir saplantı olarak nitelendirmektedir. O'Guinn ve Faber (1989: 148) tarafından bireyin tekrarladığı, kontrol edilemeyen, dürtüsel satın alma eğilimi gösteren davranış olarak tanımlanan kompulsif tüketici davranışının; madde bağımlılı̆ı, kumar oynama ve yeme bozukluklarına kadar bağımlılık yapan davranışlara benzer belirtileri olduğu ifade edilmektedir.

Kompulsif tüketiciler, tekrar tekrar satın alma gerçekleştirme konusunda kontrol edilemeyen dürtüleri olan bireylerdir. Bu nedenle Magee (1994: 590) kompulsif satın almayı, ciddi toplumsal ve kişisel sonuçları olan bir olgu olarak nitelemektedir. Benzer doğrultuda Wang, He ve Yin (2016: 582) de çoğu durumda, kompulsif tüketicilerin alışveriş bağımlıı̆ı̆ını kontrol edemediğini ve bu durumun bazen ciddi sonuçlara yol açabildiğini savunmaktadır. Eroğlu (2016) da Türk tüketiciler için söz konusu davranışın, "kompulsif satın almadan" ziyade "alışveriş bağımlılığı" şeklinde gerçekleştiğini ileri sürmektedir.

Kompulsif satın almayı, dört farklı evreden oluşan bir süreç olarak açıklayan Black (2007: 126), ilk evreyi bireyin gerçekleştirmek istediği satın almaya ilişkin düşüncenin oluşması olarak tanımlamaktadır. Bu evreyi bireyin ne zaman, nerede ve nasıl satın alma gerçekleştireceğine ilişkin hazırlığın olduğu süreçten 
oluşan ikinci evre takip etmektedir. Üçüncü evre ise gerçek alışverişin yapıldığı satın alma faaliyetinden oluşmaktadır. Dördüncü ve son evre ise, çoğunlukla alışveriş sonrası pişmanlık ve hayal kırıklığından oluşmaktadır.

Ekonomik, sosyal ve psikolojik sonuçlara neden olan kompulsif satın alma olgusu, tüketici davranışı araştırmacıları tarafından sıklıkla çalışılan bir konudur (Magee, 1994: 590). Farklı alışveriş dürtülerinden kaynaklandığı düşünülen kompulsif satın alma, pazarlama akademisyenleri ve uygulayıcılarının ilgisini çeken marka ya da mağazayla ilgili tutum ve davranışları etkileyebilmektedir (Horváth ve Van Birgelene, 2015: 5). Tüketici davranışlarında, artan yoğunlukta kompulsif satın alma gözlemlenmesi, pazarlama alanında bu konuya ilişkin yapılan çalışmaların artmasını da beraberinde getirmiştir.

Kompulsif satın alma eğiliminin kredi kartı kullanımıyla doğru orantılı olduğunu çalışmalarıyla ortaya koyan O'Guinn ve Faber'a (1989: 149-155) göre kompulsif satın alma kısa vadede olumlu hisler yaratsa da uzun vadede olumsuz sonuçlar doğuracaktır. Kompulsif ve normal tüketicileri karşılaştırdıkları çalışmalarında Horváth ve Van Birgelene (2015), kompulsif tüketicilerin satın alma esnasında duygusal ve sosyal faydalara değer vermekle birlikte genellikle satın alımlarında çeşitlilik arayışı içerisinde ve "daha ucuz" arayışında oldukları bulgusuna ulaşmışlardır. Araştırmaya konu olan diğer tüketicilerin ise markalı ürünlerin fonksiyonel faydalarına odaklandıklarını ve markasız ürün satın almaktansa sakındıkları gözlemlenmiştir. Ayrıca kompulsif tüketicilerin düşük derecede marka bağlılı̆ı ve güvenine sahip olduklarını, marka ya da mağazaları sıklıkla değiştirdiklerine dair göstergeleri olduğunu tespit etmişlerdir.

\subsection{Materyalizm}

Materyalizmi, Richins ve Dawson (1992: 308), bireylerin maddiyata verdikleri önemi hayatlarının merkezi olarak görmesine dair değerler ve inançlar dizisi olarak tanımlamışlardır. Ward ve Wackman (1971: 422) ise maddiyatı, bireyin mutlu olma ve sosyalleşme amacıyla kullanması olarak açıklamışlardır. Tüketici yönelimi olan materyalizm, tüketicinin maddi varlıklara verdiği önemi yansıtmaktadır (Belk, 1985). Benzer doğrultuda bir tanımlamada, keyif ve mutluluk arayışında, aşırı tüketim odaklı yönelim ve maddi varlıklara verilen yüksek önem materyalizm olarak kabul edilmiştir (Ger ve Belk, 1999: 184). Mevcut tüketici kültürünün temelini materyalist değerlerin oluşturduğunu savunan Dittmar (2005: 472), söz konusu değerlerin içselleştirilmesi için satın alma davranışına yönelimin arttığını ifade etmektedir.

Materyalizm modern toplumların ayırt edici özelliklerinden biridir (Wang, 2016: 582). Materyalist eğilimi yüksek tüketiciler, satın almanın hayatları için önemli, iyi bir başarı göstergesi ve hayattan sağlanacak memnuniyet için gerekli olduğu ve artan tüketim seviyelerinin onları mutlu edeceği inancına sahiptir. Daha materyalist bireyler, yaşamdan mutlu olma ve tatmin sağlama gibi amaçlarına yönelik gerçekleştirdikleri satın almalarında stratejik davranırlar (Xu, 2008: 39).

Materyalizm, felsefe, din bilimi, psikoloji, siyasal iktisat, sosyoloji, ekonomi, antropoloji ve tüketici araştırmalarında çalışma konusu olarak yer bulmaktadır (Fourner ve Richins, 1991: 403-406). Söz konusu yazarlar, tüketici araştırmalarında materyalizmin, kişisel özellik ya da davranışsal eğilim yerine genellikle değer olarak incelendiğini ifade etmişlerdir. Yaptıkları çalışmanın sonucunda ise materyalist bir yaşam tarzının düşünüldüğü gibi tamamen mutluluk ve tatmin sağlamadığını ortaya koymuşlardır.

Materyalizmi bir kişilik özelliği olarak tanımlayan Belk (1985), sahip olma isteği, cimrilik, özentilik gibi alt unsurlarla kavramı ele almıştır. Materyalizm bağlamında sahip olma isteği; bireylerin kontrolünü ya da mülkiyetini elinde tutma eğilimi olarak, cimrilik ya da cömert olmama; başkalarıyla sahip olduklarını paylaşmayı istememe olarak ve imrenmeyi ise; sahip olanlara benzeme eğilimi olarak açıklanmaktadır.

Birçok çalışma için temel kaynak olarak görülen Richins ve Dawson (1992:303-311) tarafından yapılan çalışmada materyalizm, tüketici değeri olarak kavramsallaştırımıştır. Yazarlar tarafından materyalizm, maddi değerler ölçeği ile başarı, sahip olma odaklılı̆ı ve mutluluk olmak üzere üç bileşenli değer odaklı olarak açıklanarak; söz konusu unsurların tüketicilerin satın alma istekliliğini etkilediği ortaya koyulmaktadır. 


\subsection{Hedonik Tüketim Eğilimi}

Tauber (1972) tarafından yapılan bir çalışmada, bireylerin sadece ihtiyaçlarını karşılamak için değil aynı zamanda hedonik nedenlerle de alışveriş yaptıkları görüşü ortaya atılmıştır. Söz konusu yazar "Insanlar niçin alışveriş yapar?" adlı çalışmasında birtakım alışveriş motivasyonları ileri sürmektedir. ilgili çalışmada alışveriş süreci, kişisel motivasyonlar ve sosyal motivasyonların bulunduğu davranış dizisi olarak tanımlanmaktadır. Bu çerçevede rol üstlenme, eğlence, kişisel doyum, yeni trendleri öğrenme, fiziksel aktivite ve duyusal uyarımı kişisel motive; sosyal deneyim, iletişim kurma, akran grubu çekiciliği, statü ve otorite sağlamak, pazarlık keyfinin ise sosyal motive olduğunu savunmaktadır.

Hirschman ve Holbrook'a (1982: 92) göre hedonik tüketim, bireyin aynı anda birden çok duyuya hitap eden çoklu duyguların fantezi ve duygusal yönleriyle gelişen deneyimler sonucu oluşan tüketici davranışıdır. Bu açıdan hedonik tüketim eğilimi, mutluluk, keyif ve duygusallık arayışındaki tüketim davranışlarını ifade etmektedir. Hedonik güdülerin katkısı tüketicilere deneyimsel ve duygusal olarak sağlanmaktadır. Hedonik güdüyle satın alma gerçekleştiren tüketicilerin alışveriş yapmayı sevme nedeni olarak süreçten zevk almaları gösterilmektedir. Söz konusu süreçte görevi veya hedefi tamamlamak bulunmamaktadır (To, Liao ve Lin, 2007: 775).

Bireyler, satın aldıkları ürünleri yalnızca kullanmak için değil aynı zamanda ifade ettikleri anlam için de satın almaktadırlar (Hirschman ve Holbrook, 1982: 92). Bu noktada araştırmacılar, potansiyel eğlence ve duygusal değerin önemini fark ettiklerinden beri, fayda odaklılığın yanı sıra alışverişin hedonik yönlerine de ilgi göstermeye başlamışlardır (Arnold ve Reynolds, 2003: 78).

Hirschman ve Holbrook (1982: 93) geleneksel tüketimle karşılaştırdıkları çalışmalarında hedonik tüketimi, geleneksel tüketimden ayıran düşünsel yapı, ürün sınıfları, ürün kullanımları ve bireysel farklııklar olmak üzere dört boyutta farklılaştığını ileri sürmektedir. Arnold ve Reynolds (2003) tüketicilerin alışveriş yapmadaki hedonik nedenleri araştırdıkları çalışmalarında hedonik alışverişi; macera arayışıyla alışveriş, haz arayışıyla alışveriş, başkaları için alışveriş, değer temelli alışveriş, sosyalleşmek için alışveriş ve fikir edinmek için alışveriş olmak üzere altı boyutta incelemiştir. To vd. (2007: 784) ise hedonik değerleri macera boyutu, sosyal boyutu, fikir elde etme boyutu, değer boyutu ve otorite ve statü boyutlarına ayırarak hedonik güdüdeki etkilerini araştırdıkları çalışmalarında analiz ettikleri veri dahilinde hedonik güdünün sadece maceradan, otorite ve statüden etkilendiğini saptamışlardır.

\section{Hipotezler ve Araştırma Modeli}

İçinde bulunduğumuz toplum, kompulsif satın almayı sağlayan bir ortam yaratmaya yardımcı olmaktadır (Magee, 1994: 593). Yapılan araştırmalar, materyalizmin hem bireysel hem de toplumsal düzeyde önemli etkilerinin olduğunu göstermektedir. Materyalizmin, tüketici satın alma modelleri, marka algısı, reklama yönelik tutum, sosyal uyum gibi çeşitli tüketici davranışlarıyla ilişkilendirildiğine rastlanmıştır (Wang, 2016: 583). Kompulsif satın alma davranışı, yalnızca ekonomik açıdan zarar vermemekte aynı zamanda sosyal sorunlara da yol açmaktadır (Wang vd. 2016: 582). Kompulsif satın alma eğilimine benzer olarak, materyalizm de toplumu etkileyen oldukça önemli ekonomik ve sosyal sonuçları olan olgudur.

Kompulsif satın alma eğilimi yüksek olanların materyalist eğilimlerinin de yüksek olduğunu çalışmasında ortaya koyan Dittmar (2005), materyalizmin kompulsif satın alma eğilimindeki etkisini yaş ve cinsiyet açısından araştırarak farklılıkları ortaya koymuştur. Dittmar (2005), materyalist eğilimi, kompulsif satın almaya yol açan ana neden olarak çalışmasında sunmuştur. Kompulsif satın alma eğilimini sosyopsikolojik yönüne odaklanarak inceleyen araştırmalarda oluşan genel sonuç, materyalizmin bireylerin kompulsif satın almanın en güçlü yönlendiricisi olmasıdır (Xu, 2008: 39). Bu çalışmaların aksine giyim sektöründe yaptıkları araştırma sonucunda, Johnson ve Attman (2009) materyalizm düzeyinin kompulsif satın alma eğiliminde etkisinin olmadığını ortaya koymuşlardır. Benzer doğrultuda, kompulsif satın almanın kişilik bozukluğu olarak tanımlandığı bir çalışmada, Zerach (2015) materyalizmin kompulsif satın alma eğilimine negatif etkisinin olduğunu tespit etmiştir. Öte yandan yakın zamanda yapılan çalışmalardan birinde, aile içi sıkıntıların yaşandığı ortamlardaki gençlerde kompulsif satın alma eğiliminin daha sık görüldüğünü çalışmalarıyla ortaya koyan Roberts, Pullig ve David (2019) materyalizmin kompulsif satın alma eğilimi 
üzerinde anlamlı ilişkisinin olduğunu saptamışlardır. Ayrıca Eroğlu (2016) ve Tokgöz (2020) tarafından da bir kişisel faktör olarak materyalizmin, kompulsif satın alma davranışında etkili olduğu ortaya koyulmuştur. Tüm bu teorik yapı doğrultusunda aşağıdaki hipotez oluşturulmuştur.

\section{$\mathbf{H}_{1}$ : Tüketicilerin materyalizm düzeylerinin artması, kompulsif satın alma eğilimlerini olumlu yönde etkilemektedir.}

Materyalist bireyler, yaşamlarının merkezine maddi varlıkları alarak, bu sahipliklerini, mutluluklarının anahtarı olarak görmektedirler (Podoshen, Li ve Zhang, 2011: 17). Hatta materyalistler için birincil hedef olarak sürekli sahip olma isteğinin olduğu ileri sürülmektedir (Fitzmaurice ve Comegys, 2006: 287). Tüketici davranışlarına yönelik tespitlerin daha sağlıklı bir şekilde yapılabilmesi için çok yönlü olan insan ögesinin hem materyalist hem de hazcı bir şekilde araştırımasını sağlamak gereklidir (Özsaçmacı, Yener ve Dursun, 2019: 75).

Genç tüketicilerin materyalist eğilimlerinin, anlık satın almalarındaki etkisinde hedonik tüketim davranışının düzenleyici etkisini ortaya koydukları çalışmada Lins vd. (2015), materyalizm ve hedonizmin çok da uzun düşünme intiyacıyla bağlantılı olmadığını ortaya koymuşlardır. Materyalist eğilimleri yüksek olan bireyler, başarı, sahip olma, statü ve mutlu olma gibi değerleri ön planda tutmaktadır (Richins ve Dawson, 1992). Hedonik tüketimde de bahsi geçen hazcı değerler ön planda tutulduğundan materyalist eğilim ile hedonik tüketim arasında ilişki olacağı düşünülmektedir. Buradan hareketle aşağıdaki hipotez geliştirilmiştir.

$\mathbf{H}_{2}$ : Tüketicilerin materyalizm düzeylerinin artması, hedonik tüketim eğilimlerini olumlu yönde etkilemektedir.

Literatürde tüketicilerin hedonik güdülerinin satın alma davranışlarına olan etkisini ortaya koyan çalışmalara sıklıkla rastlanırken; hedonik güdülerin kompulsif satın alma davranışlarındaki etkisine ilişkin çalışma sınırlı sayıdadır (Kukar-Kinney, Ridgway ve Monroe, 2009; Kukar-Kinney, Scheinbaum ve Schaefers, 2016; Horvárt ve Adıgüzel, 2018).

Modern çevrenin değişmesiyle birlikte tüketicilerin kompulsif satın alımını etkileyen faktörler çok daha karmaşık hale gelmiştir (Wang vd., 2016). Günümüzde satın alma faaliyetleri önemli, kolay erişilebilir ve sosyal olarak onaylanmış bir eğlence ve yaşam tarzı etkinliği halini almıştır. Dolayısıyla, tüketiciler daha fazla haz elde etme ve kısa sürede tatmin sağlama gibi hedonistik amaçlar ile alışveriş gerçekleştirmektedir. Bu eğilimlerin ise dünya çapında kompulsif satın almanın artmasına neden olması muhtemeldir (Horvárt ve Adıgüzel, 2018: 300).

Hedonik güdüler, satın alma esnasında yaşanan keyif ve heyecan gibi pozitif hisler ile ilgilidir. Kompulsif tüketicilerin de satın alma esnasında duygusal hislerinin artış yaşadığı düşünülmektedir. Söz konusu durumun ise satın alma sürecinde oluşan olumlu duyguların kompulsif tüketicileri daha fazla satın almaya motive ettiği ileri sürülmektedir (Kukar-Kinney vd., 2009: 300). Bir diğer çalışmada Kukar-Kinney vd. (2016), alışveriş motivasyonlarını inceledikleri çalışmalarında çevrimiçi ortam alışverişlerinde kompulsif tüketicilerin, diğer tüketicilere göre daha yüksek hedonik motivasyon yaşadıklarını ortaya koymuşlardır. Teorik bulgular değerlendirildiğinde kompulsif satın almada materyalizm ile birlikte etkili olan bir diğer güçlü faktörün hedonik tüketim eğilimi olduğu düşünülmektedir. Bu doğrultuda aşağıdaki hipotez geliştirilmiştir.

$\mathrm{H}_{3}$ : Tüketicilerin hedonik tüketim eğilimlerinin artması, kompulsif satın alma eğilimlerini olumlu yönde etkilemektedir.

Teorik olarak kurgulanan hipotezleri gösteren şekil, araştırma modeli olarak aşağıda sunulmuştur (Şekil 1). 
Şekil 1. Araştırma Modeli

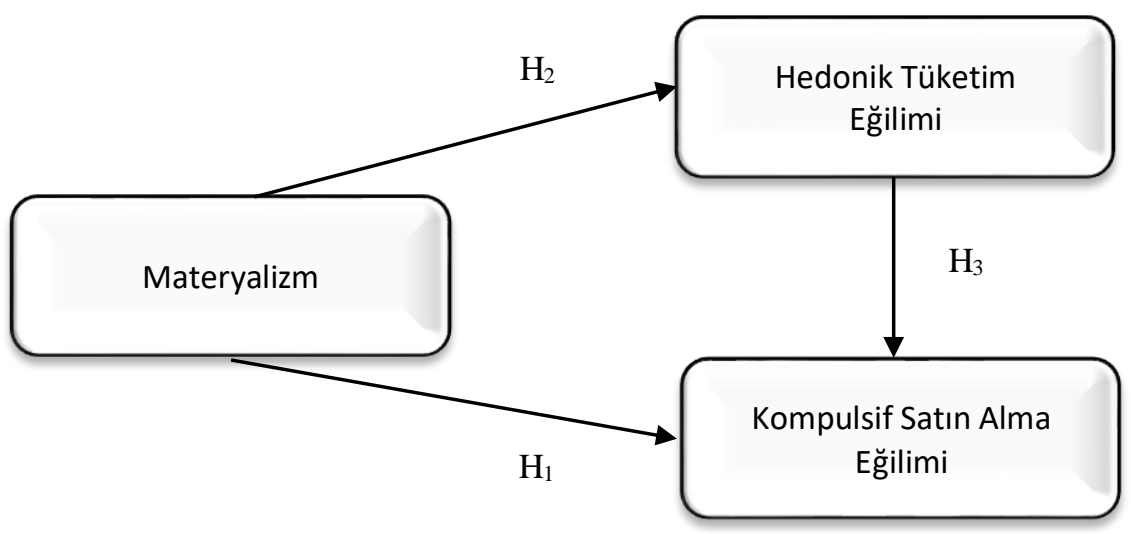

\section{Tasarım ve Yöntem}

Bu çalışma ile kompulsif satın alma eğiliminin yordayıcılarını (hedonik tüketim eğilimi ve materyalizm) eş zamanlı olarak tanımlayan ampirik bir model oluşturarak materyalizm, hedonik tüketim eğilimi ve kompulsif satın alma eğilimi üzerine literatürü geliştirmeye katkıda bulunmak istenmektedir. Mevcut çalışmada bireyin satın alma sürecindeki materyalizm, hedonik tüketim ve kompulsif satın alma eğilimi üzerinde durulmaktadır. Bu doğrultuda analiz düzeyi birey olarak ifade edilebilir.

Yapılan ampirik çalışmalarda, kompulsif satın alma eğilimi olan bireylerin \%80'inin kadın olduğu ortaya koyulmuştur (Black, 2007). Kadın tüketicilerde kompulsif satın alma eğiliminin daha yaygın olduğu bulgusuna ulaşanlardan bir diğer araştırmacı grubu, Koran vd.'ne (2006) göre tüketim ürünleri satın almanın sosyal ve kişisel kimlikleri nedeniyle erkeklere göre kadınların daha fazla kompulsif tüketici olma riskini artırmaktadır. Benzer doğrultuda hedonik tüketim eğiliminde de cinsiyete göre farklılaşmanın olup olmadığına ilişkin çalışmalar bulunmaktadır (Özdemir ve Yaman, 2007; Tifferet ve Herstein, 2012; Borges, Babin ve Spielmann, 2013). Bu çalışmalarda da tıpkı kompulsif satın alma eğilimi gibi hedonik tüketim eğiliminin kadın tüketicilerde çok daha yaygın görülen bir durum olduğu bulgularına ulaşılmıştır. Tüketici davranışlarındaki cinsiyet farklılaşmasına ilişkin yapılan çalışmalarda, araştırma kapsamındaki değişkenlerde, kadınların erkeklere oranla belirgin düzeyde farklıık oluşturması nedeniyle bu araştırmanın, aktüel ürün grubundan satın alma gerçekleştiren kadın tüketiciler üzerinde yapılması uygun bulunmuştur.

Çalışmanın ana kütlesi, daha önce aktüel ürün grubundan satın alma işlemi gerçekleştiren kadın tüketicilerden oluşmaktadır. Sekaran ve Bougie'nin (2016) 1 milyon ve üzeri ana kütlenin temsil edilebilirliği için önerdiği ve ilgili literatürde büyük oranda kabul gören örneklem büyüklüğü 384'tür. Benzer şekilde, Yazıcıoğlu ve Erdoğan (2004) da \%95 güvenilirlik düzeyinde ana kütle temsili için gerekli minimum sayının 384 olduğunu ifade etmektedirler. Ana kütleden seçilecek minimum örneklem büyüklüğünün, ankette yer alan madde sayısının en az 10 katı olması gerektiği (Büyüköztürk, 2002; Kline, 2011), özellikle Yapısal Eşitlik Modellemesi yapılacak olan çalışmalarda ise 100 sayısının asgari, 200 sayısının da kabul edilebilir sınırlarda olduğu ileri sürülmektedir (Hoelter, 1983; Barrett, 2007). Örneklemin belirlenmesine yönelik çalışmalar dikkate alındığında, ana kütlenin temsilini artıracağı düşünülen en yüksek örnekleme ulaşma gayreti içerisinde bulunulmuştur. Araştırmada kullanılan veri, daha önce aktüel ürün satın alan kadın tüketicilerden kolayda örnekleme yöntemiyle belirlenen 420 gönüllü katılımcıdan Nisan-Haziran 2018 tarihleri arasında, sosyal mecralarda çevrimiçi anket yöntemiyle toplanmıştır. Elde edilen veri analize hazır hale getirildikten sonra 395 geçerli veri analizde kullanılmıştır.

Anket formu iki bölümden oluşmaktadır. İlk bölümde demografik bilgileri ölçmeye yönelik sorular katılımcılara yöneltilirken, ikinci bölümde ise araştırma modelinde yer alan değişkenlere ilişkin literatürde kabul gören ölçekler bulunmaktadır. Amaç doğrultusunda oluşturulan uygulama bölümünde söz konusu 
ölçeklere ilişkin ifadeler 5'li Likert tipi ölçeğe göre düzenlenmiştir (1-Kesinlikle Katılmıyorum, 2-Katılmıyorum, 3-Ne Katılıyorum Ne Katılmıyorum, 4-Katılıyorum, 5-Kesinlikle Katılıyorum).

Kompulsif satın alma ölçeği (KOM) Ridgway, Kukar-Kinney ve Monroe (2008) tarafından geliştirilen tek boyut ve altı ifadeden; materyalizm ölçeği (MAT) Richins (2004) tarafından geliştirilen tek boyut ve üç ifadeden; son olarak hedonik tüketim eğilimi ölçeği (HED) ise Park, Kim ve Forney (2006) tarafından geliştirilen tek boyut ve üç ifadeden oluşmaktadır. Söz konusu ölçeklerin Türkçeye uyarlanmasında ise Brislin'in (1970) önerdiği yöntem kullanılmıştır. Bu doğrultuda önerilen çeviri-geri çeviri yöntemiyle, uzman görüşleri katkısıyla uyarlama gerçekleştirilmiştir. Araştırma kapsamında kullanılan ölçeklerin anlaşılırlığının kontrolü için otuz kişiden oluşan örneklem grubuna ön test yapılmıştır. Sonrasında ölçeklerin kullanıma hazır olduğu görüşüne varılmıştır.

Araştırma kapsamında ileri sürülen araştırma modelinin testi ve ilgili analizlerin yapılabilmesi için SPSS ve SmartPLS paket programları kullanılmıştır. Geçerli ve güvenilir bir ölçeğin varlığı, araştırmadan isabetli sonuçlar elde edilebilmesinde önemli bir aşamadır (Byrne, 2010). Bu kapsamda ilk olarak, ölçeklerin geçerliliğinin testi için açıklayıcı faktör analizi gerçekleştirilmiş, ölçeklerin güvenilirliği için iç tutarlılık katsayısı olarak Cronbach alfa değerlerine bakılmıştır. Sonrasında, araştırma modelinde yer alan değişkenler arasındaki ilişkileri tespit edebilmek amacıyla SmartPLS yardımıyla yapısal eşitlik modellemesi gerçekleştirilmiştir.

Yapısal eşitlik modellemesi, gözlenen değişkenler arasındaki ilişkileri tanımlayarak teorik modelin test edilmesine imkân vermektedir (Schumacker ve Lomax, 2010). Çoklu değişkenler arasındaki ilişkileri açıklayabilmek amacıyla kullanılan model takımı olan yapısal eşitlik modellemesi, sosyal bilim alanındaki araştırmalarda kullanılan güçlü bir istatistiksel yöntemdir (Hair, Black, Babin ve Anderson, 2014a).

PLS yapısal eşitlik modeli, bağımlı gizil değişkenlerin açıklanan varyansını maksimize etmeyi amaçlayan bir nedensel modelleme yöntemidir (Hair, Hult, Ringle ve Sarstedt, 2014b: 27). SmartPLS, pazarlama gibi çeşitli disiplinlerde değişkenlere yüklenen gözlenen yapı grupları arasındaki ilişkilerin daha iyi anlaşımasını sağlayan varyans tabanlı bir yöntemdir (Soh, Rezaei ve Gu, 2017: 189). Verinin normal dağılıp dağılmadığını önemsemeyen Smart PLS, küçük örneklem gruplarından elde edilen verinin analizinde "Bootstraping" işlemi yardımıyla kullanılabilmektedir (Hair vd., 2014b).

\section{Bulgular}

Anket formunun ilk bölümünde kadın katılımcılara yöneltilen medeni durum, yaş, eğitim durumu, aylık gelir ve mesleğe ilişkin demografik bilgilerin bulunduğu örneklem özellikleri Tablo 1'de sunulmuştur.

Tablo 1. Katılımcıların Demografik Özellikleri

\begin{tabular}{lcc}
\hline Medeni Durum & Frekans & Yüzde (\%) \\
\hline Bekâr & 259 & 65,6 \\
Evli & 136 & 34,4 \\
Yaş & & \\
\hline $18-24$ & 99 & 25,1 \\
$25-30$ & 163 & 41,3 \\
$31-35$ & 79 & 20 \\
$36-40$ & 37 & 9,3 \\
41 ve üzeri & 17 & 4,3 \\
Eğitim Durumu & & \\
\hline İköğretim & 21 & 5,3 \\
Lise & 68 & 17,2 \\
Ön Lisans & 35 & 8,9 \\
Lisans & 191 & 48,3 \\
Lisansüstü & 80 & 20,3
\end{tabular}


Tablo 1. Katılımcıların Demografik Özellikleri (Devamı)

\begin{tabular}{lcc} 
Aylık Gelir & & \\
\hline 0-1500TL & 137 & 34,7 \\
1501TL-2500TL & 106 & 26,8 \\
2501TL-3500TL & 56 & 14,2 \\
3501TL-4500TL & 50 & 12,7 \\
4501TL ve üzeri & 46 & 11,6 \\
Meslek & & \\
\hline Öğrenci & 51 & 12,9 \\
Ev Hanımı & 50 & 12,6 \\
Kamu Sektör Çalışanı & 147 & 37,2 \\
Özel Sektör Çalışanı & 116 & 29,4 \\
Esnaf & 3 & 0,8 \\
Serbest Meslek & 28 & 7,1 \\
Toplam & $\mathbf{3 9 5}$ & $\mathbf{1 0 0}$ \\
\hline
\end{tabular}

Örneklem özelliklerinin tespitinin ardından araştırma kapsamında ölçeklerin geçerlilik ve güvenilirlik analizleri yapılmıştır. Araştırma doğrultusunda katılımcılara uygulanan anket formunda yer alan cevaplama tekniği olarak Likert tipinin seçildiği ifadelerde, cevapların ayırt edilip edilemediğinin ortaya koyulabilmesi için cevapların bağımsızlık kontrolü testinin gerçekleştirilmesi gereklidir. Örneğin, Kesinlikle Katılmıyorum, Katılmıyorum, Ne Katılıyorum Ne Katılmıyorum, Katılıyorum, Kesinlikle Katılıyorum şeklinde seçenekler bulunduğunda, katılımcının bu cevapları ne kadar birbirinden bağımsız değerlendirerek cevap verebilirliğini ortaya koyabilmek amacıyla parametrik olmayan ki-kare analizi uygulanmalıdır (Kavak, 2017: 252). Söz konusu analizin yapılmasının ardından ifadelere ilişkin p değerlerinin 0,000 (Kavak, 2017: 255) düzeyinde elde edilmesiyle, katılımcıların cevap seçenekleri arasındaki farkı anladıkları ortaya koyulmuştur.

Tablo 2'den görüldüğü üzere ölçeklere ait tespit edilen KMO değerleri $(\geq 0,50)$, verilerin faktör analizine uygun olduğunu göstermektedir (Kaiser, 1974). Ölçeklere ait elde edilen öz değerler (>1), ölçeklerin tek bir faktör tarafından açıklandığını göstermektedir. Açıklanan varyans değerleri ise \%50'den büyük olarak tespit edilmiştir (Çokluk, Şekercioğlu ve Büyüköztürk, 2014). Yapılan analizler ile değişkenlerin tek bir boyutlu olduğu ortaya koyulmuştur. Değişkenlere ait faktör yüklerinin $(>0,60)$ de anlamlı olduğu görülmüştür (Büyüköztürk, 2002). Elde edilen Cronbach Alfa değerleri $(>0,81)$ ile de ölçeklerin çok güvenilir olduğu sonucuna varılmıştır (Nakip, 2006).

Tablo 2. Ölçeklere iliş̧kin Geçerlilik ve Güvenilirlik Analizi

\begin{tabular}{|c|c|c|c|c|c|c|}
\hline Değişkenler & Madde & $\begin{array}{l}\text { Faktör } \\
\text { Yükleri }\end{array}$ & $\begin{array}{c}\text { Cronbach } \\
\text { Alfa }\end{array}$ & KMO & Öz Değer & $\begin{array}{c}\text { Açıklanan } \\
\text { Varyans } \\
\text { Yüzdesi (\%) }\end{array}$ \\
\hline \multirow{6}{*}{ Kompulsif Satın Alma Eğilimi } & KOM1 & 0,904 & \multirow{6}{*}{0,891} & \multirow{6}{*}{0,827} & \multirow{6}{*}{3,968} & \multirow{6}{*}{66,134} \\
\hline & KOM2 & 0,879 & & & & \\
\hline & KOM3 & 0,863 & & & & \\
\hline & KOM4 & 0,792 & & & & \\
\hline & KOM5 & 0,738 & & & & \\
\hline & KOM6 & 0,679 & & & & \\
\hline \multirow{3}{*}{ Materyalizm } & MAT1 & 0,942 & \multirow{3}{*}{0,866} & \multirow{3}{*}{0,866} & \multirow{3}{*}{2,396} & \multirow{3}{*}{79,881} \\
\hline & MAT2 & 0,918 & & & & \\
\hline & MAT3 & 0,816 & & & & \\
\hline \multirow{3}{*}{ Hedonik Tüketim Eğilimi } & HED1 & 0,928 & \multirow{3}{*}{0,893} & \multirow{3}{*}{0,742} & \multirow{3}{*}{2,486} & \multirow{3}{*}{82,865} \\
\hline & HED2 & 0,906 & & & & \\
\hline & HED3 & 0,896 & & & & \\
\hline
\end{tabular}


Verilerin analize uygun olup olmadığını ortaya koyabilmek için normallik testi yapılmıştır. Verilerin normal dağılıp dağılmadığını ortaya koyabilmek için Kolmogorov-Simirnov testi yapılmıştır. Test sonucunda $p$ değerlerinin 0,05'ten küçük olması durumu (Gürbüz ve Şahin, 2016: 245) veri dağılımının normal olmadığını göstermektedir. Özellikle normal olmayan veri analizinde kullanılan SmartPLS ile analizin gerçekleştirilmesi uygun bulunmuştur. Bu doğrultuda SmartPLS yardımıyla yapısal eşitlik modellemesi gerçekleştirilmiştir.

Araştırma kapsamında, ele alınan ölçeklerin geçerlilik ve güvenilirlik testinin ardından, yapısal eşitlik modellemesi kullanılacağından, yapı geçerliliği ve yapı güvenilirliği testinin uygulanması da gerekmektedir (Hair vd., 2014a: 619). Örtük değişkene yüklenen gözlenen değişkenlerin içsel güvenilirliğinin tespiti için kullanılan yapı güvenilirliğinin 0,70 ya da daha yüksek bir değer alması gereklidir (Hair vd., 2014a: 605). Yapı geçerliliğinin sağlanabilmesi için ise birleşme ve ayrım geçerliliği değerlerine bakılmalıdır (Hair vd., 2014a: 619). Birleşme geçerliliğinin sağlanabilmesi için Ortalama Açıklanan Varyans (AVE) değerlerinin 0,50 ya da daha üstünde değer alması gereklidir (Hair vd., 2014a: 605).

Kompulsif satın alma eğilimi, materyalizm ve hedonik tüketim eğilimi kavramlarını ölçen üç değişken esas alınarak araştırma modeli oluşturulmuştur. Her bir değişkenin farklı bir kavramı ölçtüğünün kontrolünü sağlamak için ise ayrım geçerliliğinin incelenmesi gereklidir. Ayrım geçerliliğinin sağlanabilmesi için ise AVE değerlerinin kareköklerinin, ilgili değişkenin diğer değişkenlerle olan korelasyon değerinden yüksek olması gereklidir. Diğer bir ifadeyle değişkenler arasındaki korelasyonların karelerinin, AVE değerlerinden düşük olması ayrım geçerliliği için gerekmektedir (Hair vd., 2014a: 605). Ulaşılan tüm değerler bir arada değerlendirildiğinde, ölçüm modeli için yapı geçerliliği ve yapı güvenilirliği sağlandığı sonucuna varılmıştır. Söz konusu değerler Tablo 3'te sunulmuştur.

Tablo 3. Yapı Güvenilirliği, Ayrım Geçerliliği ve Birleşme Geçerliliği

\begin{tabular}{|c|c|c|c|c|c|c|}
\hline Değişkenler & CR & AVE & $\sqrt{A V E}$ & 1 & 2 & 3 \\
\hline 1.Kompulsif Satın Alma Eğilimi & 0,935 & 0,661 & 0,813 & & & \\
\hline 2.Materyalizm & 0,920 & 0,798 & 0,893 & 0,622 & & \\
\hline 3.Hedonik Tüketim Eğilimi & 0,922 & 0,828 & 0,909 & 0,555 & 0,563 & \\
\hline
\end{tabular}

Çalışma kapsamında cevabı aranan durumlara yönelik doğrudan ilişkilerin test edildiği üç hipotezin yer aldığı, analiz edilen modelin sonuçları Tablo 4'te sunulmuştur. İlgili tablodan görülebileceği üzere her üç hipotezden alınan sonuç da beklenti doğrultusunda desteklenmiştir. Buna göre materyalizmin kompulsif satın alma eğilimi üzerinde istatistiki olarak anlamlı ve olumlu etkisi $\left(\beta_{\text {MAT }} \rightarrow_{\text {KOM }}=0,453, t=8,19, p<0,01\right.$ ); materyalizmin hedonik tüketim eğilimi üzerinde istatistiki olarak anlamlı ve olumlu etkisi ( $\beta_{\text {MAT }} \rightarrow_{\text {HED }}=0,563$, $t=7,79, p<0,01$ ) ve hedonik tüketim eğiliminin kompulsif satın alma eğilimi üzerinde istatistiki olarak anlamlı ve olumlu etkisinin ( $\beta_{\text {HED }} \rightarrow_{\text {KOM }}=0,300, t=3,10, p<0,01$ ) olduğu bulgularına ulaşılmıştır. Ayrıca analiz sonucunda materyalizmin ve hedonik tüketim eğiliminin, kompulsif satın alma eğilimini \%32 düzeyinde $\left(R^{2}\right.$ ком); materyalizmin ise hedonik tüketim eğilimini \%45 düzeyinde $\left(R^{2}\right.$ HED) açıklama gücüne sahip olduğu görülmüştür.

Tablo 4. Analiz Sonuçları

\begin{tabular}{lccccc}
\hline & $\begin{array}{c}\text { Std. } \\
\text { Beta Değeri }\end{array}$ & t-değeri & $\begin{array}{c}\text { Std. } \\
\text { Hata Değeri }\end{array}$ & $\begin{array}{c}\text { Açıklanma } \\
\text { Değeri }\left(\mathbf{R}^{2}\right)\end{array}$ & $\begin{array}{c}\text { Hipotez } \\
\text { Sonuçları }\end{array}$ \\
\hline $\mathbf{H}_{1}$ : MAT->KOM & 0,453 & 8,1901 & 0,0760 & $0,32\left(R^{2}{ }_{\text {KOM }}\right)$ & Desteklendi \\
H $_{2}$ MAT->HED & 0,563 & 7,7940 & 0,0723 & $0,45\left(R^{2}{ }_{\text {HED }}\right)$ & Desteklendi \\
H $_{3}$ HED->KOM & 0,300 & 3,1043 & 0,0966 & & Desteklendi \\
\hline
\end{tabular}

Değişkenler arası belirtilen tüm ilişkilerde $p<0,01$ düzeyinde anlamlıdır $(t>2,576)$. 

Bir Araştırma

Araştırma kapsamında ele alınan modelde, materyalizm değişkeninin kompulsif satın alma eğilimindeki doğrudan etkisine ilaveten, hedonik tüketim eğilimi üzerinden dolaylı bir etkisi de söz konusudur. Bu durum ise Tablo 5'te sunulmuştur.

Tablo 5. Değişkenler Arasındaki Dolaylı ve Toplam Etkiler

\begin{tabular}{|c|c|c|c|c|c|c|}
\hline & \multicolumn{3}{|c|}{ Dolaylı Etkiler } & \multicolumn{3}{|c|}{ Toplam Etkiler } \\
\hline & MAT & HED & KOM & MAT & HED & KOM \\
\hline MAT & & & & & & \\
\hline HED & & & & 0,563 & & \\
\hline ком & 0,453 & & & 0,622 & 0,300 & \\
\hline
\end{tabular}

Değişkenler arası belirtilen tüm ilişkilerde $p<0,01$ düzeyinde anlamlıdır $(t>2,576)$.

Araştırma kapsamında test edilen model, bulguları ile birlikte grafiksel olarak Şekil 2'de sunulmuştur.

Şekil 2. Araştırma Modelinin Path Diyagramı

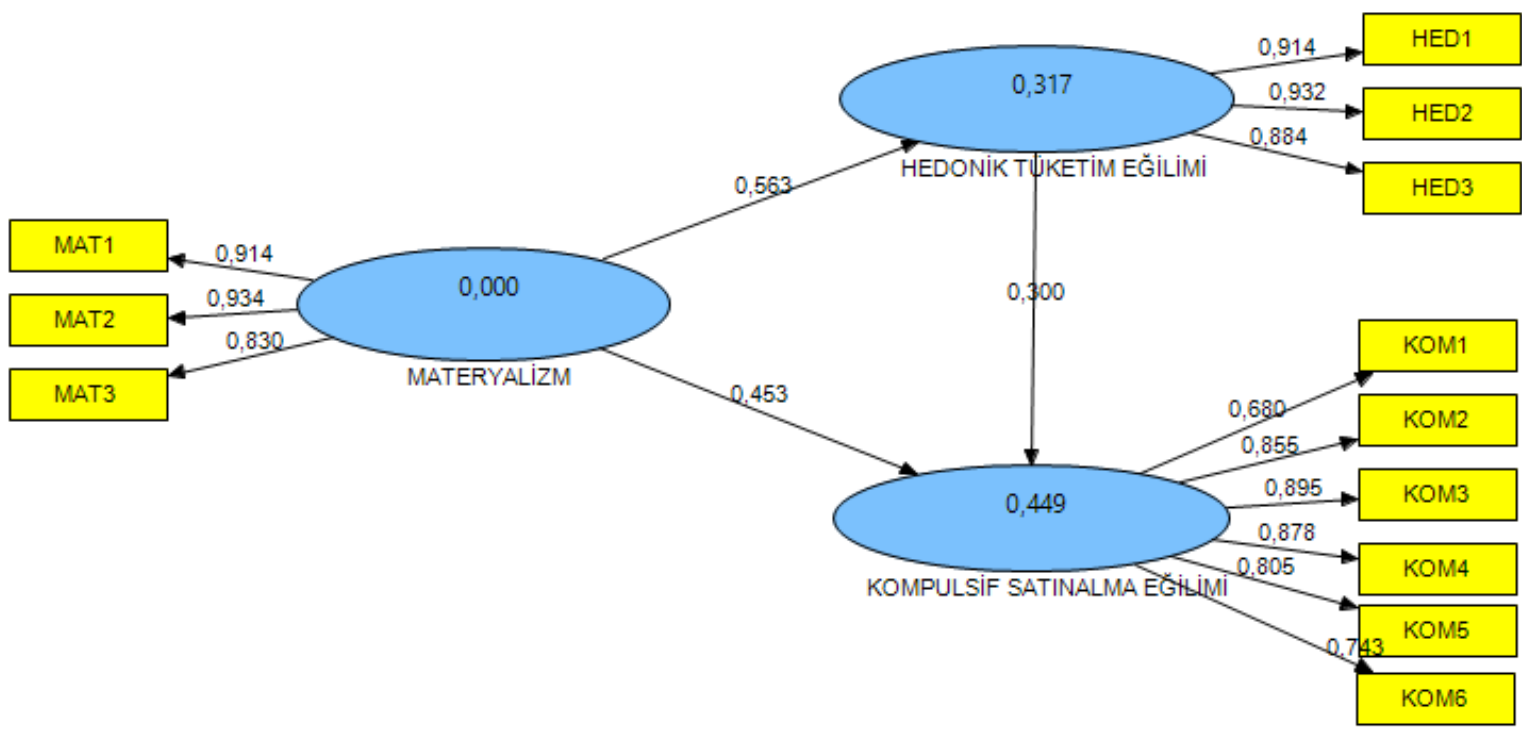

\section{Sonuç}

Bu çalışmanın amacı, aktüel ürün tüketen kompulsif kadın tüketicilerin psikolojik yönlendiricilerine ilişkin bazı davranışsal öncüllerini incelemektir. Mevcut araştırma, tüketici davranışları perspektifinden, kompulsif satın alma eğiliminin materyalizm ve hedonik tüketim eğilimi ile olan ilişkisini ortaya koymak amacıyla yapılmıştır. Farklı tüketim alışkanlıklarının gözlemlendiği günümüzde, materyalist eğilimlerin, hedonik tüketim ve kompulsif satın almanın incelenmesinin önem arz ettiği düşünülmektedir. Önerilen hipotezler doğrultusunda, materyalizm ve kompulsif satın alma eğilimi; materyalizm ve hedonik tüketim eğilimi ve hedonik tüketim eğilimi ile kompulsif satın alma eğilimindeki yapısal ilişkiler test edilmiştir.

Araştırma kapsamında öne sürülen modele ilişkin elde edilen bulgular, araştırmaya dâhil olan kadın tüketicilerin sahip oldukları materyalist eğilimlerin kompulsif satın alma davranışı üzerinde etkili olduğunu ortaya koymaktadır. Mevcut çalışmanın sonuçlarında Johnson ve Attman (2009) ve Zerach (2015)'ın bulgularının aksi yönünde; Roberts vd. (2019), Dittmar (2005) ve Xu (2008)'nun bulgularıyla ise benzer doğrultuda, materyalist eğilimlerin tüketicileri kompulsif satın alma eğilimine yönlendirdiği ortaya koyulmuştur. 
Tüketim kültürüne ilişkin kavramlar olan hedonizm ve materyalizmin birbirlerine olan etkisine bakıldığında ise materyalizmin, hedonik tüketim eğilimini etkilediği bulgusuna ulaşıımıştır. Araştırmadan elde edilen bulgularda ise kadın tüketicilerin aktüel ürün satın alırken, hedonik tüketim eğilimlerinin kompulsif satın alma eğilimlerinde etkii olduğu görülmüştür. Bu bulgu, Kukar-Kinney vd. (2009) ile Horvárt ve Adıgüzel (2018) tarafından yapılan çalışmaları da destekler niteliktedir.

Yoğun rekabetin yaşandığı günümüz pazarlarında farklılaşan tüketici ihtiyaçları, farklılaşan ürün gruplarını beraberinde getirmiştir. Perakendecilik sektöründe artan rekabet nedeniyle, işletmeler mağazalarını aktüel ürün grubuyla cazip hale getirmeye çalışmaktadır. Özellikle aktüel ürün grubu ile tüketicileri mağazalarına çekmek isteyen pazarlama uygulayıcıları, bu tüketicilerin genellikle materyalist eğilimlerle hedonik tüketim ve kompulsif tüketim gerçekleştirdiklerini bilerek strateji hazırlamalıdır. Reklam kampanyalarını hazırlarken ulaşılan bu bulgudan yararlanabilirler.

Mutluluğun tüketime dayalı yönelimi olarak nitelenen materyalizmin, tüketicilerin hem hedonik tüketim hem de kompulsif satın alma eğilimlerinde etkili olduğu görülmüştür. Bu çalışma, aktüel ürün grubu açısından kadın tüketicilerin kompulsif satın alma, materyalizm ve hedonik tüketim eğilimleri konusunda ilgili literatüre ve uygulamaya dönük katkılar içermesine rağmen bazı kısıtlara da sahiptir. Toplanan veri, ankete katılan tüketicilerin öznel ifadelerine dayandığı ve tesadüfi olmayan örnekleme yöntemlerinden olan kolayda örnekleme yöntemiyle sağlandığı için, bulgular neticesinde ulaşılan sonuçların bu kısıtlar çerçevesinde değerlendirilmesi yerinde olacaktır.

Illeride yapılacak çalışmalarda, benlik imajı, öz kontrol gibi psikolojik unsurların kompulsif satın almayla ilişkili olabileceği düşünülen faktörlerle araştırma modeli genişletilebilir. Mevcut çalışmada belirtilen nedenlerden dolayı kadın tüketiciler üzerinde araştırma gerçekleştirilmiştir. Gelecekte yapılacak çalışmalarda erkek tüketiciler de çalışmaya dâhil edilerek kadın ve erkeklere ilişkin bulgular karşılaştırılabilir.

\section{Beyan ve Açıklamalar (Disclosure Statements)}

1. Bu çalışmanın yazarı, araştırma ve yayın etiği ilkelerine uyduğunu kabul etmektedir (The author of this article confirms that her work complies with the principles of research and publication ethics).

2. Yazar tarafından herhangi bir çıkar çatışması beyan edilmemiştir (No potential conflict of interest was reported by the author).

3. Bu çalışma, intihal tarama programı kullanılarak intihal taramasından geçirilmiştir (This article was screened for potential plagiarism using a plagiarism screening program).

\section{Kaynaklar}

Akçi, Y., \& Kılınç, K. (2016). Aktüel ürün perakendecilerine ilişkin tüketici görüşlerinin incelenmesi. International Journal of Social Science, 49(1), 305-327.

Arnold, M. J., \& Reynolds, K. E. (2003). Hedonic shopping motivations. Journal of Retailing, 79(2), 77-95.

Barrett, P. (2007). Structural equation modelling: Adjudging model fit. Personality and Individual Differences, 42, 815824.

Başfırıncı, C., Ük, Z. Ç., \& Gültekin, Y. (2019). Türkiye'deki indirim marketlerinin marka imajlarının sosyal ağ analizi yöntemiyle incelenmesi: A101, BiM ve ŞOK örneği. Uluslararası Ekonomi ve Yenilik Dergisi, 5(2), 277-300.

Belk, R. W. (1985). Materialism: Trait aspects of living in the material world. Journal of Consumer Research, 12(3), 265280.

Bhatia, V. (2019). Impact of fashion interest, materialism and internet addiction on e-compulsive buying behaviour of apparel. Journal of Global Fashion Marketing, 10(1), 66-80.

Black, D. W. (2007). Compulsive buying disorder: A review of the evidence. CNS Spectrums, 12(2), 124-132.

Borges, A., Babin, B. J., \& Spielmann, N. (2013). Gender orientation and retail atmosphere: effects on value perception. International Journal of Retail \& Distribution Management, 41(7), 498-511.

Brislin, R. W. (1970). Back-translation for cross-cultural research. Journal of Cross-Cultural Psychology, 1(3), 185-216. 
Büyüköztürk, Ş. (2002). Faktör analizi: Temel kavramlar ve ölçek geliştirmede kullanımı. Kuram ve Uygulamada Eğitim Yönetimi, (32), 470-483.

Byrne, B. M. (2010). Structural equation modeling with EQS and EQS/Windows: Basic concepts, applications, and programming (2nd Edition). New York: Taylor and Francis Group.

Çokluk, Ö., Şekercioğlu, G., \& Büyüköztürk, Ş. (2014). Sosyal bilimler için çok değişkenli istatistik SPSS ve Lisrel uygulamaları (3. Baskı). Ankara: Pegem Akademi.

DeSarbo, W. S., \& Edwards, E. A. (1996). Typologies of compulsive buying behavior: A constrained clusterwise regression approach. Journal of Consumer Psychology, 5(3), 231-262.

Dittmar, H. (2005). Compulsive buying-a growing concern? An examination of gender, age, and endorsement of materialistic values as predictors. British Journal of Psychology, 96(4), 467-491.

Eroğlu, F. (2016). Kompulsif satın alma: Kişisel faktörler, postmodern tüketim şekilleri ve reklama karşı tutumun rolüne yönelik bir araştırma. Balıkesir Üniversitesi Sosyal Bilimler Enstitüsü Dergisi, 19(35), 253-282.

Fitzmaurice, J., \& Comegys, C. (2006). Materialism and social consumption. Journal of Marketing Theory and Practice, 14(4), 287-299.

Fournier, S., \& Richins, M. (1991). Some theoretical and popular notions concerning materialism. Journal of Social Behavior and Personality, 6(6), 403-414.

Ger, G., \& Belk, R. W. (1999). Accounting for materialism in four cultures. Journal of Material Culture, 4(2), $183-204$.

Gürbüz, S., \& Şahin, F. (2016). Sosyal bilimlerde araştırma yöntemleri felsefe-yöntem-analiz (3. Baskı). Ankara: Seçkin Yayıncilık.

Hair, J. F. Jr., Black, W. C., Babin, B. J., \& Anderson, R. E. (2014a). Multivariate data analysis (7th Edition). New Jersey: Pearson Prentice Hall.

Hair, J. F., Hult, G. T. M., Ringle, C. M., \& Sarstedt, M. (2014b). A primer on partial least squares structural equation modeling. Thousand Oaks: Sage Publications.

Hirschman, E. C., \& Holbrook, M. B. (1982). Hedonic consumption: Emerging concepts, methods and propositions. Journal of Marketing, 46(3), 92-101.

Hoelter, J. W. (1983). The Analysis of covariance structures: Goodness-of-hit indices. Sociological Methods \& Research, $11,325-344$.

Horváth, C., \& Adıgüzel, F. (2018). Shopping enjoyment to the extreme: Hedonic shopping motivations and compulsive buying in developed and emerging markets. Journal of Business Research, 86, 300-310.

Horváth, C., \& Van Birgelen, M. (2015). The role of brands in the behavior and purchase decisions of compulsive versus noncompulsive buyers. European Journal of Marketing, 49(1/2), 2-21.

Johnson, T., \& Attmann, J. (2009). Compulsive buying in a product specific context: clothing. Journal of Fashion Marketing and Management, 13(3), 394-405.

Kaiser, H. F. (1974). An index of factorial simplicity. Psychometrika, 39(1), 31-36.

Kavak, B. (2017). Pazarlama ve pazar araştırmaları tasarım ve analiz (2. Baskı). Ankara: Detay Yayıncılık.

Kline, R. B. (2011). Principles and practice of structural equation modeling (3rd Edition). New York: Guilford Press.

Koran, L. M., Faber, R. J., Aboujaoude, E., Large, M. D., \& Serpe, R. T. (2006). Estimated prevalence of compulsive buying behavior in the United States. American Journal of Psychiatry, 163(10), 1806-1812.

Kukar-Kinney, M., Ridgway, N. M., \& Monroe, K. B. (2009). The relationship between consumers' tendencies to buy compulsively and their motivations to shop and buy on the Internet. Journal of Retailing, 85(3), 298-307.

Kukar-Kinney, M., Scheinbaum, A. C., \& Schaefers, T. (2016). Compulsive buying in online daily deal settings: An investigation of motivations and contextual elements. Journal of Business Research, 69(2), 691-699.

Lins, S., Dóka, Á., Bottequin, E., Odabašić, A., Pavlović, S., Merchán, A., Golasa, A., \& Hylander, F. (2015). The effects of having, feeling, and thinking on impulse buying in European adolescents. Journal of International Consumer Marketing, 27(5), 414-428.

Magee, A. (1994). Compulsive Buying Tendency as a Predictor of Attitudes and Perceptions. Advances in Consumer Research, 21(1), 590-594.

Nakip, M. (2006). Pazarlama araştırmaları teknikler ve (SPSS Destekli) uygulamalar (2. Baskı). Ankara: Seçkin Yayıncılık.

O'Guinn, T. C., \& Faber, R. J. (1989). Compulsive buying: A phenomenological exploration. Journal of Consumer Research, 16(2), 147-157. 
Özdemir, Ş., \& Yaman, F. (2007). Hedonik alışverişin cinsiyete göre farklılaşması üzerine bir araştırma. Eskişehir Osmangazi Üniversitesi iiBF Dergisi, 2(2), 81-91.

Özsaçmacı, B., Yener, D., \& Dursun, T. (2019). Hedonizm, hedonik tüketim ve tüketimde materyalist eğilimler üzerine bir araştırma. Üçüncü Sektör Sosyal Ekonomi Dergisi, 54(1), 71-88.

Park, E. J., Kim, E. Y., \& Forney, J. C. (2006). A structural model of fashion-oriented impulse buying behavior. Journal of Fashion Marketing and Management, 10(4) 433-446.

Podoshen, J. S., Li, L., \& Zhang, J. (2011). Materialism and conspicuous consumption in China: A cross-cultural examination. International Journal of Consumer Studies, 35(1), 17-25.

Richins, M. L. (2004). The positive and negative consequences of materialism: What are they and when do they occur? Advances in Consumer Research, 31, 232-235.

Richins, M. L., \& Dawson, S. (1992). A consumer values orientation for materialism and its measurement: Scale development and validation. Journal of Consumer Research, 19(3), 303-316.

Ridgway, N. M., Kukar-Kinney, M., \& Monroe, K. B. (2008). An expanded conceptualization and a new measure of compulsive buying. Journal of Consumer Research, 35(4), 622-639.

Roberts, J. A., Pullig, C., \& David, M. (2019). Family conflict and adolescent compulsive buying behavior. Young Consumers, 20(3), 208-218.

Schumacker, R. E., \& Lomax, R. G. (2010). A Beginner's guide to structural equation modeling (3rd Edition). New York: Taylor \& Francis Group.

Sekaran, U., \& Bougie, R. (2016). Research methods for business: A skill building approach (7th Edition). West Sussex: John Wiley \& Sons.

Soh, C. Q. Y., Rezaei, S., \& Gu, M. L. (2017). A structural model of the antecedents and consequences of Generation Y luxury fashion goods purchase decisions. Young Consumers, 18(2), 180-204.

Tauber, E. M. (1972). Why do people shop? Journal of Marketing, 36(4), 46-49.

Tifferet, S., \& Herstein, R. (2012). Gender differences in brand commitment, impulse buying, and hedonic consumption. Journal of Product \& Brand Management, 21(3), 176-182.

To, P. L., Liao, C., \& Lin, T. H. (2007). Shopping motivations on internet: A study based on utilitarian and hedonic value. Technovation, 27(12), 774-787.

Tokgöz, E. (2020). Impact of materialistic values on impulsive and compulsive consumption via status consumption: A research on young consumers. Business and Economics Research Journal, 11(1), 261-278.

Wang, Y. (2016). Social stratification, materialism, post-materialism and consumption values. Asia Pacific Journal of Marketing and Logistics, 28(4), 580-593.

Wang, Y., He, X. Q., \& Yin, X. (2016). The Impact of consumer materialism in China on online compulsive buying behavior. Wuhan International Conference on e-Business, 582-589.

Ward, S., \& Wackman, D. (1971). Family and media influences on adolescent consumer learning. American Behavioral Scientist, 14(3), 415-427.

$\mathrm{Xu}, \mathrm{Y}$. (2008). The influence of public self-consciousness and materialism on young consumers' compulsive buying. Young Consumers, 9(1), 37-48.

Yazıcıoğlu, Y., \& Erdoğan, S. (2004). SPSS uygulamalı bilimsel araştırma yöntemleri. Ankara: Detay Yayıncılık.

Zerach, G. (2015). The mediating role of emptiness and materialism in the association between pathological narcissism and compulsive buying. International Journal of Mental Health and Addiction, 14(4), 424-437. 
This Page Intentionally Left Blank 